Creative commons User License: CC BY-NC-ND

Abstracted by: EBSCOhost, Electronic Journals Service (EJS), Google Scholar, Journal Seek, Scientific Commons,

Food and Agricultural Organization (FAO), CABI and Scopus
Journal of Agricultural Extension

Vol. 22 (1) February, 2018

ISSN(e): 24086851; ISSN(Print); $1119944 X$

http://journal.aesonnigeria.org.

http://www.ajol.info/index.php/jae

Email: editorinchief@aesonnigeria.org

\title{
Impact of Agricultural Services and Training Centre Project on Tomato Farmers' Livelihood in Plateau State, Nigeria \\ https://dx.doi.org/10.4314/jae.v22i1.4
}

\author{
Momoh, Onaivi Yakubu \\ Federal College of Land Resources Technology, \\ Dept of Agricultural Extension and Management \\ Kuru- Jos, Plateau State. \\ E-mail: momohonaivi@yahoo.com. \\ Phone number: +2348064741242 .
}

\author{
Akpoko, Joseph Gambo \\ Ahmadu Bello University, Department of Agricultural Economics and Rural Sociology, \\ Zaria, Kaduna State. \\ Email: josephgamboakpoko@gmail.com \\ Phone number: +2348033973686 .

\section{Akinola, Mathew Olu} \\ Ahmadu Bello University, Department of Agricultural Economics and Rural Sociology, \\ Zaria, Kaduna State. \\ E- mail: moluakins59@yahoo.com \\ Phone number: +2347067694919.
}

\section{Abstract}

This study assessed the impact of Agricultural Services and Training Centre (ASTC) on tomato farmers' livelihood in Plateau State, Nigeria. A multi-stage sampling procedure was used for this study. Firstly, a purposive sampling was used to select three Local Government Areas ( $L G A)$ out of each three senatorial zones and three villages from each LGAs while random and purposive sampling were used to select 206 participants in ASTC project and 206 non- participants, making a total sample size of 412 farmers in Plateau State. Questionnaire and interview schedule were used for data collection and analyzed with descriptive statistics and inferential statistics such as chow test model. The result revealed $90 \%$ and $77 \%$ males of the participants and the non-participants respectively while the females were $10 \%$ and $23 \%$ participants and the non- participants respectively. Chow test model analysis indicated a positive mean on output $F=149.87)$, income, $(F=3.95)$ and level of living ( $F=24.24)$ of the participants' farmers in ASTC project than the nonparticipant farmers in the project. The output, income and level of living difference were significant at 5\% level of probability which means a significant difference in output, income and level of living of farmers participating in ASTC tomato production. It was concluded that ASTC project intervention had positive impact on tomato production and livelihood of participant farmers in the study area. The study therefore recommends that the existing cooperative society included in the ASTC project be sustained in order to consolidate the achievement of the participating farmers in the scheme.

Keywords: Participation, Intervention, Livelihoods. 
Creative commons User License: CC BY-NC-ND

Abstracted by: EBSCOhost, Electronic Journals Service (EJS),

Google Scholar, Journal Seek, Scientific Commons,

Food and Agricultural Organization (FAO), CABI and Scopus
Journal of Agricultural Extension

Vol. 22 (1) February, 2018

ISSN(e): 24086851; ISSN(Print); 1119944X

http://journal.aesonnigeria.org.

http://www.ajol.info/index.php/iae

Email: editorinchief@aesonnigeria.org

\section{Introduction}

Everywhere around the world, agricultural production is central to the overall wellbeing of the populace because of its importance in the provision of foods, income for farmers, raw materials for industries, employment and foreign exchange for the nation. National Bureau of Statistics/Central Bank of Nigeria (2006) stated that agricultural production provides for $2 / 3$ of Nigerians who are low income earners and it is presently one of the world largest producers of food and raw materials for its major enterprise. However, Nigeria is still facing serious food shortages to meet up the need of ever increasing population in the country which has manifested in food shortages.

In a bid to solve the declining food challenges, the Federal and State Government of Nigeria initiated many food production policies and programmes over the years to tackle the daunting challenges faced in the farming sector. For instance, the Operation Feed the Nation (OFN), the Directorate of Foods, Roads and Rural Infrastructures (DFRRI), the National Accelerated Food Production Programme (NAFPP), National Agricultural Land Development Authority (NALDA), and others, while past projects in Plateau State are: Bokkos Farm Project, Longkat Irrigation Scheme, Sabon Gida Gagnom Farm Project, Kuru Livestock Complex Project and Panyam Fish. Besides, these programmes and a number of other ones, failed to meet the target of self-sufficiency in food production and increases in income of farmers substantially. This situation raised serious concern regarding Nigeria's vision of becoming one of the world's twenty strongest economies by the year 2020 .

Despite Nigeria's rank of $2^{\text {nd }}$ to Egypt in Africa and $13^{\text {th }}$ position in the world hierarchy of tomato production, the country is still lagging behind in tomato production compared to Egypt and USA. Nigeria still imports 65,809 tonnes of processed tomato annually, worth over N11.7 Billion despite its massive local production (CBN, 2012). The yield of tomato in Nigeria is low, the average in guinea savannah zones of the country being only 20 tonnes per hectares (FAO, 2010). For instance, Nigeria production was estimated at $1,860,600$ tonnes in 2010 while the United State of America had an estimate for the same year as 12,858,700 tonnes (FAO, 2010). Yield per hectare in Nigeria was estimated at $1 / 7^{\text {th }}$ of that of the USA (FAO, 2010). Besides, within the Africa context the estimated annual average yield per hectare of tomato in Nigeria is at 7.1 tonnes per hectare comparable to 39.5 tonnes per hectare for Egypt (CBN, 2012). This short fall necessitated the importation of processed tomato worth $\mathrm{N} 11.7$ billion (\$75.5million) yearly. The fact is that Nigeria only produces between 20-30 percent domestically far from expectation. Besides, 25-50 percent of the import of this domestic paste is from China (CBN, 2011) thus leaving the market for domestically produced tomato paste underserved. This makes Nigeria one of the primary importers of tomato globally and a major consumer of tomato paste. 
Creative commons User License: CC BY-NC-ND

Abstracted by: EBSCOhost, Electronic Journals Service (EJS), Google Scholar, Journal Seek, Scientific Commons,

Food and Agricultural Organization (FAO), CABI and Scopus
Journal of Agricultural Extension

Vol. 22 (1) February, 2018

ISSN(e): 24086851; ISSN(Print); 1119944X

http://journal.aesonnigeria.org.

http://www.ajol.info/index.php/iae

Email: editorinchief@aesonnigeria.org

In the same vein, the Government of Plateau State in 2008 entered into a joint venture agreement with an Israeli "SEC" company specialized in agricultural development and thus initiated and implemented the Agricultural Services and Training Centre (ASTC) intervention project, as an alternative approach, with emphasis on tomato production. The vision is aimed at agrarian reform through the introduction of modern farming techniques referred to as protective farming system with inputs inclusion package, which makes tomato production attractive, create employment opportunities for the youths, and to prove that agriculture could serve as the nation's dependable and sustainable alternative source of income /revenue generation. In pursuance of this objective, a comprehensive Farm Centre has been established and operated in each of the three Senatorial Zones of the State. However, since six years of inception now, billions of Naira had been invested in the implementation of the project; very few empirical studies have been available to confirm the intended impact in Plateau State (ASTC bulletin 2012). This has constituted a gap in knowledge that needs to be filled making this study particularly imperative. According to Delta State Ministry of Agriculture (2004) research findings show that the reasons for failure of past development programmes were poor data base used for policy formulation. Besides, without adequate evaluation, one cannot be sure whether the objectives of the project were comprehensively achieved. It is therefore necessary to assess the impact of the project on the target population.

Food and Agriculture Organisation (1986) asserted that most development experts often remain frustrated by the limited success of most programmes, occasioned by small scale farmers frequently rejecting or partially participating in a programme regardless of how the agency's design and formulation demonstrate higher levels of productivity.

\section{Objective of the study}

The broad objective of this study was to assess the impact of Agricultural services and training centre project on tomato farmers' livelihoods in Plateau State, Nigeria.

The specific objectives were to:

i. identify the socio-economic characteristics of the project participants and nonparticipants in the study area; and

ii. examine the impact of ASTC intervention project on the output of tomato production, income and livelihoods of tomato farmers' livelihoods.

\section{Methodology}

Plateau State is located in the northern middle belt area of Nigeria. It shares boundary to the West with Kaduna State, to the North with Bauchi State, to the Southern part with Benue State, and to the East with Taraba and Nasarawa States. The State has Seventeen Local Government 
Creative commons User License: CC BY-NC-ND

Abstracted by: EBSCOhost, Electronic Journals Service (EJS),

Google Scholar, Journal Seek, Scientific Commons,

Food and Agricultural Organization (FAO), CABI and Scopus
Journal of Agricultural Extension

Vol. 22 (1) February, 2018

ISSN(e): 24086851; ISSN(Print); 1119944X

http://journal.aesonnigeria.org.

http://www.ajol.info/index.php/jae

Email: editorinchief@aesonnigeria.org

Areas and has Jos town as its headquarters. It is classified into three senatorial zones which are Northern, Southern and Central zones. It lies between the latitude of $80^{\circ} 24^{1}$ and longitude of $80^{\circ} 32^{\prime}$ and $10^{\circ} 38^{\prime}$ East of the Greenwich Meridian. It is situated in the tropical zone, with a higher altitude ranges from 12 metres about 400 feet to a peak of 1829 meters above sea level. The State covers a total land area of 53,585 square kilometres (FOS, 2006). It has a population of $3,178,712$ persons consisting of $1,593,033$ males and 1,585,679 females with a population growing rate of $2.7 \%$ per annum (NPC, 2006).

This study employed a multi stage sampling technique. In the first stage, three Local Government Areas were purposively selected from each of the three senatorial zones which are Jos-south, Barkin-Ladi, Bassa, Shendam, Quanpan, Wase, Bokkos, Mangu and Kanam making a total of nine Local Government Areas, due to major ASTC activities on tomato production in the zones. In the second stage, three villages having high ASTC participating farmers were purposively selected making a total of twenty- seven villages. Reconnaissance survey was conducted to identify registered participating tomato farmers of ASTC in the State. This was carried out with the assistance of Agricultural Extension Agent in the first stage. The third stage was based on random selection of $50 \%$ of 420 sampling frame of participant farmers of ASTC activities, making 210 participating farmers, while fifty percent $50 \%$ of 420 non- participating farmers which is (210) were purposively selected because of high concentration of tomato farmers in the study areas. In all, 420 farmers were selected.

The primary data was used as sources of information for this study. Primary data were collected from participating and non-participating farmers, using questionnaires, interview schedule and assistance of ASTC extension agents. But 206 questionnaires were returned.

The analytical tools used for objectives of the study were the descriptive statistics used for objective i and Chow test model was used for objective ii to measure the impact of ASTC intervention project on output, income and level of living of the participants and nonparticipants. In programme evaluation, the chow test is often used to determine whether the independent variables have different impact on different sub groups of the population (Mohammad, 2014). The model for chow test is expressed mathematically as:

$F *$ Chow $=\frac{\left(R S S_{3}-S S R_{1}+S S R_{2}\right) / K}{\left(\mathrm{RSS}_{1}+\mathrm{RSS}_{2}\right) / \mathrm{n}_{1}+\mathrm{n}_{2}-2 \mathrm{k}}$.

Where; $\mathrm{RSSR}_{3}=$ the sum of squared residuals from a linear regression in which $\mathrm{b}_{1}$ and $b_{2}$ are assumed to be the same (pooled data).

$\mathrm{SSR}_{1}=$ the sum of squared residuals from a linear regression of sample 1 (participants)

$\mathrm{SSR}_{2}=$ the sum of squared residuals from a linear regression of sample 2 (Nonparticipants). 
Creative commons User License: CC BY-NC-ND

Abstracted by: EBSCOhost, Electronic Journals Service (EJS), Google Scholar, Journal Seek, Scientific Commons,

Food and Agricultural Organization (FAO), CABI and Scopus
Journal of Agricultural Extension

Vol. 22 (1) February, 2018

ISSN(e): 24086851; ISSN(Print); 1119944X

http://journal.aesonnigeria.org.

http://www.ajol.info/index.php/iae

Email: editorinchief@aesonnigeria.org

Both have dimension $\mathrm{k}$ and these are number of observation in total. The total number of observation is; $\mathrm{K}=$ is the total number of regression estimates including intercept of $\mathrm{N}_{1}+$ $\mathrm{N}_{2}=$ number of observation of the regression of sample 1 and 2 (participants and nonparticipants). The decision rule for this model is that if Chow F-statistics is greater than that of F-table at $5 \%$ level of probability it then means that ASTC has made impact on the (output, income and level of living). This means there is a structural difference between the participant and non- participant farmers and if otherwise there is no impact of ASTC in the study area.

\section{Results and Discussion}

\section{Socio-economic characteristics of the respondents}

Table: 1 reveals that $89.8 \%$ of the project participants are males while $72.2 \%$ for nonparticipants are males. The dominance by males may be attributed to land ownership system that prevails in the area. This allows only male members of the society to inherit and own land. Besides, the majority of $(72.8 \%)$ of participants and $(71.8 \%)$ of non-participant farmers examined fall within the age bracket of 31-40 years. This constitutes the age bracket of active labour force that is innovative and productive. Also, the majority (83.5\%) of the participating farmers and $(81.6 \%)$ of non-participating farmers were married. This means that farmers have higher engagement and commitment towards the project in order to support family livelihoods than the unmarried. The result also revealed that $87.3 \%$ and $89.8 \%$ of the participants and non- participants respectively have some form of education. This implies that respondents' level of participation, interpretation of information and adoption of ASTC services will be made easier and accelerated. The result revealed that the majority $(78.2 \%$ and $75.2 \%)$ of the beneficiaries and nonbeneficiary farmers respectively have family size of 6-8. This level of household size implies the availability of family labour for tomato production. Also, the majority of the participants' farmers (52.9\%) are members of ASTC cooperative society while $(78.6 \%)$ of non-participant farmers are not members of cooperative society. This implies that membership of ASTC cooperative society creates an opportunity for the participating farmers to share views on tomato production. The implication of non- membership of ASTC cooperative society shows that the individual farmer may likely face some challenges in tomato production and ideas may not be shared. A scenario that often leads to ineffective and inefficient use of resources consequently resulting to low output of tomato production. 
Creative commons User License: CC BY-NC-ND

Abstracted by: EBSCOhost, Electronic Journals Service (EJS), Google Scholar, Journal Seek, Scientific Commons,

Food and Agricultural Organization (FAO), CABI and Scopus
Journal of Agricultural Extension

Vol. 22 (1) February, 2018

ISSN(e): 24086851; ISSN(Print); 1119944X

http://journal.aesonnigeria.org.

http://www.ajol.info/index.php/jae

Email: editorinchief@aesonnigeria.org

Table 1: Socio-economic characteristics of respondents

\begin{tabular}{|c|c|c|}
\hline & Participants & Non-Participants \\
\hline \multicolumn{3}{|l|}{ Sex } \\
\hline Male & 89.8 & 77.2 \\
\hline Female & 10.2 & 22.8 \\
\hline \multicolumn{3}{|l|}{ Age } \\
\hline,$<20$ & 0.0 & 0.0 \\
\hline $20-30$ & 6.8 & 4.9 \\
\hline $31-40$ & 72.8 & 71.8 \\
\hline $41-50$ & 12.1 & 12.6 \\
\hline $51-60$ & 2.4 & 4.9 \\
\hline $61-70$ & 3.9 & 4.4 \\
\hline $71-80$ & 1.9 & 1.5 \\
\hline \multicolumn{3}{|l|}{ Marital status } \\
\hline Married & 83.5 & 81.6 \\
\hline Single & 10.7 & 12.6 \\
\hline Widow & 5.8 & 5.8 \\
\hline \multicolumn{3}{|l|}{$\begin{array}{l}\text { Educational } \\
\text { qualification }\end{array}$} \\
\hline $\begin{array}{l}\text { No formal education } \\
\text { Household size }\end{array}$ & 1.9 & 2.4 \\
\hline $3-5$ & 3.4 & 3.9 \\
\hline $6-8$ & 78.2 & 75.2 \\
\hline $9-11$ & 16.5 & 17.5 \\
\hline 12 & 1.9 & 3.4 \\
\hline \multicolumn{3}{|l|}{$\begin{array}{l}\text { Membership of } \\
\text { cooperative society }\end{array}$} \\
\hline Yes & 52.9 & 21.4 \\
\hline No & 47.1 & 78.6 \\
\hline
\end{tabular}

Source: Field Survey 2015

\section{Impact of ASTC on the Output of Participant and Non- Participant}

Result on Table 2 of Chow test shows that a ASTC project and tomato output of the participants at (Chow test $=149.87$ at $5 \%$ level of significance). This implies that the participation of farmers in ASTC project has brought a sign finding is line with that of Chukwuemeka (2012) that observed that most assisted programmes by the government helped in promoting small-scale autonomous enterprise, increased production, and marketing and training in the project. 
Creative commons User License: CC BY-NC-ND

Abstracted by: EBSCOhost, Electronic Journals Service (EJS), Google Scholar, Journal Seek, Scientific Commons,

Food and Agricultural Organization (FAO), CABI and Scopus
Journal of Agricultural Extension

Vol. 22 (1) February, 2018

ISSN(e): 24086851; ISSN(Print); 1119944X

http://journal.aesonnigeria.org.

http://www.ajol.info/index.php/jae

Email: editorinchief@aesonnigeria.org

Table 2: Impact of ASTC on the output of participant and non- participant farmers

\begin{tabular}{llllll}
\hline $\begin{array}{l}\text { Group } \\
\text { Sample }\end{array}$ & $\mathbf{R}^{2}$ & $\begin{array}{l}\text { Residual sum } \\
\text { square }\end{array}$ & of & $\mathbf{N}$ & $\mathbf{K}$ \\
\hline $\begin{array}{l}\text { Pooled } \\
\text { samples }\end{array}$ & 0.738 & 118547474.121 & 412 & 10 \\
participants & 0.458 & 19606179.872 & 206 & \\
$\begin{array}{l}\text { Non- } \\
\text { participants }\end{array}$ & 0.521 & 3072658.231 & 206 & \\
\hline $\begin{array}{l}R^{2}=\text { regression coefficient, } \\
\end{array}$ & & &
\end{tabular}

Impact of ASTC on Income of Participant and Non- Participant

Result from Table: 3 reveals that significant relationship exists between ASTC project and the income of participating farmers at (Chow $\mathrm{F}$ calculated $=3.952$ at $5 \%$ level of significance). This implies that higher income has been realized from the sales of higher output thus translating to better condition of eking out a living by the participating farmers. This is in line with Tologbonse (2013) findings in the study of factors influencing women participation in Women in Agriculture programme of Kaduna State Agricultural Development Project. It was observed that the mean income of participants was 134 , 389. 04 which was higher than the mean income of $(\$ 5,605$. 35) for the non-participants in Kaduna State.

Table 3: Impact of ASTC on the income of participant and non- participant farmers.

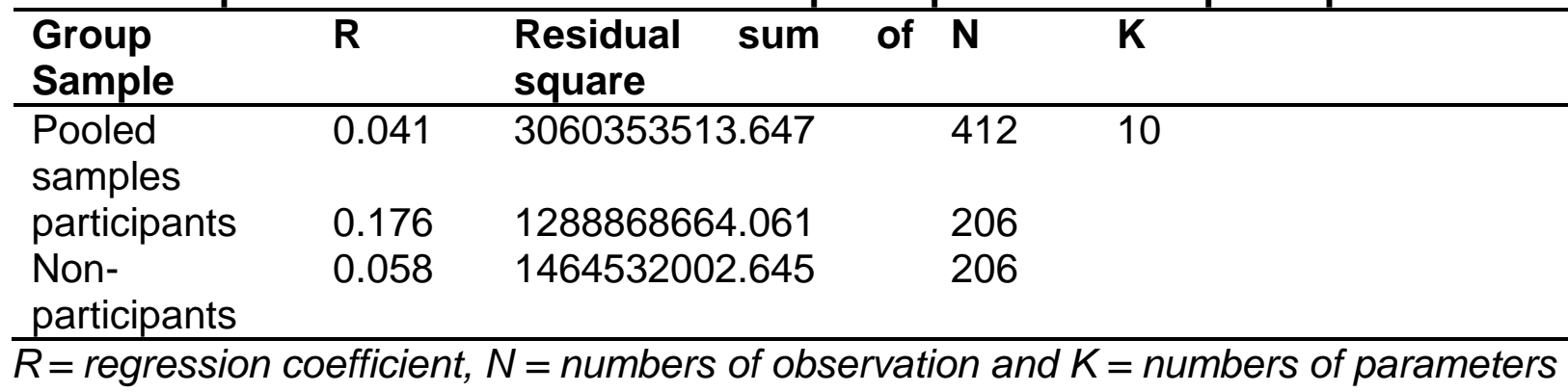

\section{Impact of ASTC on Level of Living of Participant and Non- Participant}

Table 4 reveals that significant relationship exists between ASTC project and level of living of participating farmers in the study area (Chow F calculated $=24.24$ at $5 \%$ level of significance) thus implying that ASTC project had made significant contributions on the level of living of participating farmers. This implies that participant farmers might have enjoyed some forms of asset in terms of increased household items and consumption or use of economic goods such as food, motor-cycle, bicycle, car, house, radio, television, motorized pump, knapsack, thresher, fuel, and other non durable goods used up, thus 
Creative commons User License: CC BY-NC-ND

Abstracted by: EBSCOhost, Electronic Journals Service (EJS), Google Scholar, Journal Seek, Scientific Commons,

Food and Agricultural Organization (FAO), CABI and Scopus
Journal of Agricultural Extension

Vol. 22 (1) February, 2018

ISSN(e): 24086851; ISSN(Print); 1119944X

http://journal.aesonnigeria.org.

http://www.ajol.info/index.php/jae

Email: editorinchief@aesonnigeria.org

signifying a significant improvement in their livelihood compared to the non-participating farmers.

Table 4: Impact of ASTC on the level of living of participant and non- participant farmers

\begin{tabular}{lllll}
\hline $\begin{array}{l}\text { Group } \\
\text { Sample }\end{array}$ & $\mathbf{R}^{2}$ & $\begin{array}{l}\text { Residual sum of } \\
\text { square }\end{array}$ & $\mathbf{N}$ & $\mathbf{K}$ \\
\hline $\begin{array}{l}\text { Pooled } \\
\text { samples }\end{array}$ & 0.139 & 534868150308.257 & 412 & 10 \\
participants & 0.026 & 293871317789.399 & 206 & \\
$\begin{array}{l}\text { Non- } \\
\text { participants }\end{array}$ & 0.063 & 65622295620.858 & 206 & \\
\hline
\end{tabular}

$R^{2}=$ regression coefficient, $N=$ numbers of observation and $K=$ numbers of parameters

\section{Conclusion and Recommendations}

The study revealed that the majority of the respondents were young, married and had one form of formal education or the other. Male farmers dominated tomato crop production with the majority cultivating less than two hectares of land for production. The output, income and level of living of the participating farmers increased significantly than the non-participating farmers. The inclusion of cooperative society in the ASTC project provides a platform for farmers' interaction contributing to the success of the project. The existing cooperative society included in the ASTC project should be sustained in order to consolidate the achievement and involvement of the existing participating farmers as well as attracting other young entrepreneurs into the scheme. The success of this project, it can be replicated in other states of the federation.

\section{References}

Agricultural Services and Training Centres (ASTC) Bulletin, (2012). Agricultural Revolution in Nigeria.

Central Bank of Nigeria, (2011). Integrating Nigeria's agricultural and financial value chains: The Role of NISAL. November 16, 2011. Retrieved from www.efina.org.ng. $7^{\text {th }}$ of May, 2012.

Central Bank of Nigeria (CBN), (2012).Harnessing Nigeria's Potential in Tomato Production-Nigeria. Retrieved from www.nigeriabestforum.com. Business and Economy. $5^{\text {th }}$ of June, 2015.

Chukwuemeka, O. K. (2012). Rural Development Trends in Nigeria: Problems and Prospect. Society for Research and Academic Excellence. Vol 4, Nsukka. 
Creative commons User License: CC BY-NC-ND

Abstracted by: EBSCOhost, Electronic Journals Service (EJS), Google Scholar, Journal Seek, Scientific Commons,

Food and Agricultural Organization (FAO), CABI and Scopus
Journal of Agricultural Extension

Vol. 22 (1) February, 2018

ISSN(e): 24086851; ISSN(Print); 1119944X

http://journal.aesonnigeria.org.

http://www.ajol.info/index.php/jae

Email: editorinchief@aesonnigeria.org

Delta State Ministry of Agricultural and Natural Resources (2004).Operation Live and Own A Farm (LOAF), Asaba.

Federal Office of Statistics (FOS), (2006). Federal Office of Statistics Survey.

Food and Agriculture Organisation, (1986). A case study of the technology application Gab: overcoming constraints: to small farm agriculture, FAO research and technology paper, 1.

Food and Agriculture Organization (FAO), (2010).Global and national tomato production (trade for fresh tomato-code 0702000), tomato news. tomato products consumption.

Food and Agriculture Organization, FAOSTAT, (2012).Food and Agriculture Organization, online statistical database. Retrieved fromhttp://faostat.fao.org/. 10 $0^{\text {th }}$ of August, 2015.

National Bureau of Statistics/Central Bank of Nigeria, (2006). Socio-economic survey on Nigeria, NBS, Abuja.

National Planning Commission (NPC) (2006). Official census report, National Population Commission, Abuja, Nigeria.

Tologbonse, E .B., Jibrin M. M., Auta, S. J and Damisa, M. A. (2013).Factors influencing women participation in Women In Agriculture (WIA) Programme of Kaduna State Agricultural Development Project, Nigeria. International Journal for Agricultural Economics and Extension ISSN: 2329-979. 1(7): 047-054.

Mohammad, N.A. (2014). Structural change and Chow Test: Revisited .Global Journal of Quantitative Science. 1(4):24-28. 